\title{
The drawbacks of learn from home: A student perspective
}

\author{
Putu Indra Christiawan ${ }^{1}$ \\ \{indra.christiawan@undiksha.ac.id $\left.{ }^{1}\right\}$ \\ Universitas Pendidikan Ganesha, Indonesia ${ }^{1}$
}

\begin{abstract}
Learn from home is an education world strategy to ensure that the teaching and learning process continues during the global pandemic Covid-19. All levels of education carry out e-learning to answer the challenges of education during periods of physical distancing, including higher education. This study aims to evaluate the online lecture process from a student's perspectives, and also measure students' motivation in participating in e-learning. Through a basic qualitative research design, data collected through online questionnaire distribution techniques to 100 respondents was taken as purposive random sampling and analyzed with analytic induction techniques. The results showed that students assessed the existence of three fundamental weaknesses in the implementation of elearning, namely the absence of a clear lesson plan, weak time management, and too many assignments given by the lecturer. Other findings show that student motivation is still relatively stable, with the primary objective of broadening horizons. However, if the learning process from home continues to run with these various weaknesses, then the motivation of students to take online lectures decreases dramatically.
\end{abstract}

Keywords: Learn from home; Covid-19; Higher education; Student perspectives; Motivation

\section{Introduction}

Learn from home is a common vocabulary during a global coronavirus disease pandemic. Learning from home is a strategic policy adopted by almost all countries affected by the Covid19 case, including Indonesia. Since the Covid-19 case began to spread, within time, to be exact March 24, 2020, through a Regulation from the Minister of Education and Culture of Republic of Indonesia, learn from home has been officially established as an effort to prevent the spread of disease outbreaks in the learning process. Home learning is intended to keep educational activities going by providing regular and regular learning activities to students [1]. When students return to school, it is expected that their learning motivation will not fade, and the learning material will not be left behind.

Even so, learn from home is still a new experience for most people. This term has never been heard before, even research publications with the keywords learn from home are hard to find. In other words, there is no clear guidance and scientific debate in the context of implementing learning activities at home, especially during the global pandemic. This problem results in different perceptions of educators towards the implementation of learning from home.

Learning in networks or better known as e-learning is a sensible choice taken by the government to implement learning from home. E-learning is a system or concept of education 
that utilizes information technology in teaching and learning. E-learning has been widely applied by educational institutions, especially in higher education, and there have been many studies that prove its effectiveness in increasing students' motivation and learning achievement [2], [3]. Furthermore, the progress of ICTs has opened up more significant opportunities to apply e-learning to various fields of science and education [4].

However, previous studies related to the application of e-learning so far are still in the context of normal situations. Covid-19's global pandemic has forced learning activities from home implemented without adequate preparation - never prepared before - not imagined to prepare it. The main actors who face this pressure are educators, both teachers and lecturers. Elearning, which is more prevalent in universities is not necessarily popular among all lecturers. Undiksha e-learning is an Open Source LMS owned by Universitas Pendidikan Ganesha (Undiksha) and can be used by all Undiksha lecturers and students. However, based on research results Utami et.al. [5], e-learning platform owned by Undiksha is still not used by stakeholders effectively. In other words, lecturers and students who use e-learning are still limited-learning from home during the pandemic forced lecturers to learn about e-learning and how to use it.

Many lecturers are radically exposed to culture shock. Without sufficient preparation time, experience, and knowledge, lecturers must provide lectures online. Other challenges are the various restrictions imposed during the Covid-19 pandemic. As a condition of force majeure, these challenges must be accepted and implemented. This new experience will have a significant impact on the learning process at the higher education level, and not a few will cause various weaknesses and losses.

Some researchers have examined the challenges faced by academics in implementing elearning. One of them, which is significant, is a study conducted by Silahuddin [6], which has succeeded in identifying five e-learning challenges faced by educators in higher education. The five challenges include cultural challenges and learning styles, pedagogical, technological, technical guidance, and time management. The five challenges are stated as limitations in the application of e-learning in higher education. These five challenges will be used as a primary consideration to understand whether students in-home learning also experience these challenges.

Other studies also revealed various weaknesses in the application of e-learning. Jara \& Mellar [7] suggested a fundamental weakness in applying e-learning in higher education is the reduction in the intensity of the interpersonal communication dimension between lecturers and students. This weakness will have an impact on decreasing effectiveness in transforming and constructing students' perspectives in understanding a problem. Methodologically this study will also reveal the intensity of interpersonal dimensions felt by students in the case of learning from home. Finally, this study will reveal the student motivation level in the learning process from home. The study used as a reference is the result of El-Seoud et.al. [3], which shows an increase in student motivation to use e-learning.

This study will evaluate the implementation of the learning process from home at the level of higher education from the student version. Similar studies in regular times though still limited to examine the effectiveness of the application of e-learning from the perspective of students. An evaluation of the implementation of learning from home in the student version is needed to build and perfect a learning system from home in the near future. The purpose of this study is to analyze how the implementation of learning from home was carried out by lecturers and measure student motivation in attending online lectures. 


\section{Method}

The research design used a basic qualitative. According to this basic qualitative design, it is intended to produce a deep understanding of learning from home from data collected from students and then analyzed in the form of descriptive narratives. This qualitative design is an approach that is generally used to understand and interpret social phenomena in their natural environment. This type of research is also often useful to further enhance understanding and crystallize research problems developed [8].

The scope of this research is focused in Indonesia, specifically on tertiary education at Universitas Pendidikan Ganesha. The selected subjects in this study were 100 social science students spread evenly in the second, fourth, sixth, and eighth semesters. A sampling of research subjects was done purposively. An online questionnaire is applied for data collection. The main purpose of this questionnaire is to understand the respondents' perspectives, opinions, and experiences about the questions asked. Semi-structured interviews are used to obtain clarification about the personal experiences and respondents' perspectives about the home learning process carried out by the lecturer. In the online questionnaire, respondents' identity and answers are kept confidential.

The data collected in this study are students' perceptions of online lecture preparation, online lecture implementation, and evaluation. The primary data was collected from the results of filling out the online questionnaire. Analytical induction techniques are used to analyze research data. Analytical induction, which is one of the typical data analysis techniques, is carried out with a stringent process in sequence to study the phenomenon under study.

\section{Result and Discussion}

E-learning, as a manifestation of home learning, has begun immediately from the policies issued by the government. In the process of implementing e-learning, it is believed that there will be variations between one lecturer and another, especially lecturers who are familiar with e-learning and lecturers who are using it for the first time. The e-learning process variations presented as a result of this study are sorted out in terms of preparation, implementation, and assessment, all of which come from student responses. In addition to presenting variations in students' perceptions of the e-learning process during the pandemic, a study related to student motivation was also presented. The motivation shown in this study is related to what is the main motivation of students and how the level of student motivation during learning activities from home. The results of the study are illustrated in the following table.

Table 1. Student Reviews of Lecturer Preparations in Online Lectures

\begin{tabular}{|c|c|c|c|c|c|c|c|c|c|c|c|}
\hline \multirow[t]{3}{*}{ No } & \multirow[t]{3}{*}{ Semester } & \multicolumn{10}{|c|}{ Preparation } \\
\hline & & \multicolumn{2}{|c|}{$\begin{array}{c}\text { No } \\
\text { lesson plan }\end{array}$} & \multicolumn{2}{|c|}{$\begin{array}{c}\text { Insufficient } \\
\text { material }\end{array}$} & \multicolumn{2}{|c|}{$\begin{array}{l}\text { Inappropriate } \\
\text { platform }\end{array}$} & \multicolumn{2}{|c|}{$\begin{array}{c}\text { Ignored student's } \\
\text { location }\end{array}$} & \multicolumn{2}{|c|}{ Total } \\
\hline & & $\mathrm{N}$ & $\%$ & $\mathrm{~N}$ & $\%$ & $\mathrm{~N}$ & $\%$ & $\mathrm{~N}$ & $\%$ & $\mathrm{~N}$ & $\%$ \\
\hline 1 & II & 11 & 44 & 0 & 0 & 0 & 0 & 14 & 56 & 25 & 100 \\
\hline 2 & IV & 10 & 40 & 5 & 20 & 0 & 0 & 10 & 40 & 25 & 100 \\
\hline 3 & VI & 10 & 40 & 5 & 20 & 5 & 20 & 5 & 20 & 25 & 100 \\
\hline 4 & VIII & 15 & 60 & 4 & 16 & 0 & 0 & 6 & 24 & 25 & 100 \\
\hline & Total & 46 & 46 & 14 & 14 & 5 & 5 & 35 & 35 & 100 & 100 \\
\hline
\end{tabular}


Table 1 shows the performance of the lecturer in preparing e-learning from the student's perspective. Based on the semester, there are differences in students' assessment of the preparation of lecturers in implementing e-learning. As many as $56 \%$ of the youngest students rate that in preparing for lectures, lecturers do not consider the location of students. While the other three batches mostly viewed that lecturers did not prepare a clear learning plan before starting online lectures, namely $40 \%$ of fourth and sixth-semester students and the most substantial, $60 \%$ of eighth-semester students. Overall, the highest percentage of student assessment of lecturer preparation is the absence of lecture scenarios, which is $46 \%$. The second position with $35 \%$ is occupied by factors that neglect students' locations, followed by insufficient lecture material (14\%), and the lowest is the use of inappropriate platforms $(5 \%)$.

Table 2. Student Review of Online Lecture Implementation

\begin{tabular}{|c|c|c|c|c|c|c|c|c|c|c|c|}
\hline \multirow[t]{3}{*}{ No } & \multirow[t]{3}{*}{ Semester } & \multicolumn{10}{|c|}{ Implementation } \\
\hline & & \multicolumn{2}{|c|}{$\begin{array}{c}\text { Time } \\
\text { consuming }\end{array}$} & \multicolumn{2}{|c|}{$\begin{array}{c}\text { No } \\
\text { explanation }\end{array}$} & \multicolumn{2}{|c|}{ Monotonous } & \multicolumn{2}{|c|}{$\begin{array}{l}\text { Internet data } \\
\text { consuming }\end{array}$} & \multicolumn{2}{|c|}{ Total } \\
\hline & & $\mathrm{N}$ & $\%$ & $\mathrm{~N}$ & $\%$ & $\mathrm{~N}$ & $\%$ & $\mathrm{~N}$ & $\%$ & $\mathrm{~N}$ & $\%$ \\
\hline 1 & II & 13 & 52 & 6 & 24 & 0 & 0 & 6 & 24 & 25 & 100 \\
\hline 2 & IV & 11 & 44 & 3 & 12 & 2 & 8 & 9 & 36 & 25 & 100 \\
\hline 3 & VI & 5 & 20 & 2 & 8 & 5 & 20 & 13 & 52 & 25 & 100 \\
\hline \multirow[t]{2}{*}{4} & VIII & 10 & 40 & 2 & 8 & 5 & 20 & 8 & 32 & 25 & 100 \\
\hline & Total & 39 & 39 & 13 & 13 & 12 & 12 & 36 & 36 & 100 & 100 \\
\hline
\end{tabular}

Table 2 shows the performance of lecturers in implementing e-learning from the perspective of students. Based on the semester, there are differences in the students 'assessment of the lecturers' actions in implementing e-learning. As many as $52 \%$ of students in the sixth semester considered that the internet data spent was very large in conducting lectures. While the other three batches mostly viewed that lecturers did not manage their time well, the time for conducting online lectures was very long, and $52 \%$ of second-semester students were the most significant, $44 \%$ of the fourth-semester, and $40 \%$ of eight-semester students. Overall, the highest percentage of student assessments of the stage of conducting online lectures was the length of time required to carry out online lectures, which was $39 \%$. The second position with $36 \%$ is occupied by wasteful use of internet data, followed by the absence of explanations from lecturers $(13 \%)$, and the lowest is a boring class $(12 \%)$.

Table 3. Student Review of Evaluations in Online Lectures

\begin{tabular}{|c|c|c|c|c|c|c|c|c|c|c|c|}
\hline \multirow[t]{3}{*}{ No } & \multirow[t]{3}{*}{ Semester } & \multicolumn{10}{|c|}{ Evaluation } \\
\hline & & \multicolumn{2}{|c|}{$\begin{array}{c}\text { Excessive } \\
\text { task }\end{array}$} & \multicolumn{2}{|c|}{$\begin{array}{c}\text { No feed } \\
\text { back }\end{array}$} & \multicolumn{2}{|c|}{$\begin{array}{c}\text { Monotonous } \\
\text { task }\end{array}$} & \multicolumn{2}{|c|}{$\begin{array}{c}\text { Short working } \\
\text { periode }\end{array}$} & \multicolumn{2}{|c|}{ Total } \\
\hline & & $\mathrm{N}$ & $\%$ & $\mathrm{~N}$ & $\%$ & $\mathrm{~N}$ & $\%$ & $\mathrm{~N}$ & $\%$ & $\mathrm{~N}$ & $\%$ \\
\hline 1 & II & 20 & 80 & 0 & 0 & 0 & 0 & 5 & 20 & 25 & 100 \\
\hline 2 & IV & 15 & 60 & 5 & 20 & 0 & 0 & 5 & 20 & 25 & 100 \\
\hline 3 & VI & 15 & 60 & 2 & 8 & 5 & 20 & 3 & 12 & 25 & 100 \\
\hline 4 & VIII & 11 & 44 & 7 & 28 & 5 & 20 & 2 & 8 & 25 & 100 \\
\hline & Total & 61 & 61 & 14 & 14 & 10 & 10 & 15 & 15 & 100 & 100 \\
\hline
\end{tabular}

Table 3 shows the performance of lecturers in evaluating e-learning from the student's perspective. Compactly, most of all students in each semester revealed that the assignments given by lecturers were numerous. This assessment is the most widely expressed by students in the second semester, which is $80 \%$. Overall, the highest percentage of student assessments of 
the evaluation stage in online lectures is too many assignments given by lecturers, which is $61 \%$. The second position with $15 \%$ is occupied by the short work period, followed by the absence of feedback from lecturers (14\%), and the lowest is that lecturers always give the same assignment $(10 \%)$.

Table 4. Main Motivation of Students in Online Lectures

\begin{tabular}{cccccccccccc}
\hline No & Semester & \multicolumn{1}{c}{ Main Motivation } \\
\cline { 3 - 13 } & & Widening knowledge & \multicolumn{1}{c}{ Imporving skill } & \multicolumn{1}{c}{ Grades } & Stay active & \multicolumn{2}{c}{ Total } \\
\cline { 2 - 13 } & & N & $\%$ & N & $\%$ & N & $\%$ & N & $\%$ & N & $\%$ \\
\hline $\mathbf{1}$ & II & 13 & 52 & 5 & 20 & 5 & 20 & 2 & 8 & 25 & 100 \\
\hline $\mathbf{2}$ & IV & 9 & 36 & 6 & 24 & 7 & 28 & 3 & 12 & 25 & 100 \\
\hline $\mathbf{3}$ & VI & 10 & 40 & 4 & 16 & 6 & 24 & 5 & 20 & 25 & 100 \\
\hline $\mathbf{4}$ & VIII & 5 & 20 & 4 & 16 & 4 & 16 & 12 & 48 & 25 & 100 \\
\hline & Total & 37 & 37 & 19 & 19 & 22 & 22 & 22 & 22 & 100 & 100 \\
\hline
\end{tabular}

Table 4 shows the primary motivations of students in e-learning. Based on the semester, there are differences in student motivation in participating in e-learning. As many as $48 \%$ of eightsemester students attend online lectures because they remain active even though they are at home. While the other three batches mostly viewed that the main motivation in online lectures was to broaden their horizons, which $52 \%$ of second-semester students as the most massive, $36 \%$ of the fourth semester, and $40 \%$ of sixth-semester students. Overall, the highest percentage of students' motivation to participate in e-learning is to increase their knowledge, which is $37 \%$. The second position with the same percentage, which is $22 \%$, is occupied by a motivation to get grades and stay active, and the lowest is to have new skills (19\%).

Table 5. Level of Student Motivation in Online Lectures

\begin{tabular}{|c|c|c|c|c|c|c|c|c|c|c|c|}
\hline \multirow[t]{3}{*}{ No } & \multirow[t]{3}{*}{ Semester } & \multicolumn{10}{|c|}{ Level of Motivation } \\
\hline & & \multicolumn{2}{|c|}{ Motivated } & \multicolumn{2}{|c|}{ Standard } & \multicolumn{2}{|c|}{ Frustated } & \multicolumn{2}{|c|}{ Desperated } & \multicolumn{2}{|c|}{ Total } \\
\hline & & $\mathrm{N}$ & $\%$ & $\mathrm{~N}$ & $\%$ & $\mathrm{~N}$ & $\%$ & $\mathrm{~N}$ & $\%$ & $\mathrm{~N}$ & $\%$ \\
\hline 1 & II & 2 & 8 & 12 & 48 & 9 & 36 & 2 & 8 & 25 & 100 \\
\hline 2 & IV & 2 & 8 & 12 & 48 & 10 & 40 & 1 & 4 & 25 & 100 \\
\hline 3 & VI & 4 & 16 & 13 & 52 & 7 & 28 & 1 & 4 & 25 & 100 \\
\hline \multirow[t]{2}{*}{4} & VIII & 6 & 24 & 14 & 56 & 5 & 20 & 0 & 0 & 25 & 100 \\
\hline & Total & 14 & 14 & 51 & 51 & 31 & 31 & 4 & 4 & 100 & 100 \\
\hline
\end{tabular}

Table 5 shows the level of student motivation in online lectures. Concisely, the majority of all students in each semester state that their motivation in attending online lectures is standard. Students most expressed this level of motivation in eight semesters, which amounted to $56 \%$. Overall, the highest percentage of students' motivation to take online lectures is at the standard level, which is $51 \%$. Surprisingly, the second position with $31 \%$ is occupied by the level of innovation, followed by a highly motivated level (14\%), and the lowest is some students feel depressed (4\%).

Based on the results of the study, there are several exciting and surprising phenomena both in terms of student assessment of the online lecture process and in terms of student motivation. First, it will discuss the weaknesses of lecturers in implementing the learning process from home. Second, it will discuss the factors that encourage students to take part in online learning.

The weakness of lecturers in implementing e-learning from the perspective of students has started from the preparation stage, which continues at the implementation stage and leads to the evaluation process. In terms of preparation, the principal lecturer is seen as not being able to 
design the full e-learning procedure. Without a precise learning scenario, students do not know how to start learning, start discussions, and also how to do the assignments given by the lecturer. Learning seems to run spontaneously and impress without a clear direction. In contrast to previous studies, a detailed learning plan design is the initial foundation that must be prepared before carrying out online learning [9]. An interesting finding is that lecturers do not consider the student's place of residence before determining the e-learning platform to be used. During the Covid-19 pandemic, students were required to learn from home and were not free to leave the house. While in some places where students come from, the internet connection is limited, as well as the electricity network. Not all students can access the platform used by lecturers, because most of them live in rural areas, and some even live in the interior. This condition certainly cannot be compared to previous research, which has found an effective strategy for implementing e-learning in remote areas [10], [11]. In this period of physical restrictions, many public places (which have internet access) have been closed, and it is also highly recommended to avoid crowds to prevent the spread of disease outbreaks. Besides, in preparing for online lectures, lecturers have not provided much material or learning references. Also, some lecturers use social media as an online lecture platform. According to Gon \& Rawekar [12], this can be done effectively, and most lecturers only have ordinary conversations. This condition will later have an impact on student readiness and potentially disrupt the implementation of online lectures.

From the online lecture implementation, the main lecturer is considered not able to manage the time of the online class efficiently. Inadequate preparation, and without adequate experience, lead to online lectures running at a slow tempo, and seemingly waiting for each other to discuss or even discuss becomes biased. So much time is needed to carry out online lectures for just one meeting. Though based on Almarabeh \& Mohammad [2] research, e-learning will create effectiveness and efficiency in learning. Nevertheless, once again, the condition of this force Majeure does not give sufficient time for lecturers to learn to manage online classes before taking action. Other deficiencies that have been identified are the use of internet data, both to download assignments or upload assignments that have been made by students. Sixth-semester students most felt this case. They are required to upload a practice teaching (microteaching) video that is almost 30 minutes each week. Although there is a data package from campus, it is considered far from enough.

On the other hand, parents' limited income makes it difficult for students to buy internet data. Besides, in conducting online lectures, few lecturers provide explanations or participate in discussions, so the implementation of online lectures also feels boring. Referring to the study of Al-Samarraie et al. [13], lecturers' active participation is crucial in the implementation of elearning. This condition will eventually impact student understanding and potentially hinder students from achieving high scores at the learning evaluation stage.

Finally, in terms of evaluation of learning, the main lecturer is considered to have given too many assignments. The form of assignment most favored by lecturers is making papers, making essays, or answering quizzes. Giving assignments is normal, but giving assignments at every meeting is something that is felt by students as unrealistic. Add more, the duration of the assignment is considered very short. Students are given one week of work time to make a paper or essay, while those who spend more energy and thought are answering quiz questions in 15 seconds per question.

Contrary to these findings, assignments, and quizzes in e-learning is the variations that students most look forward [7]. However, too frequent assignments and too short work hours make the task becomes a frightening specter for students. Besides, in the evaluation process, lecturers rarely give feedback on assignments that have been collected by students. Lecturers 
also only give the same type of assignment from time to time. They reflected on the research of King et.al. [14], stating that the provision of fast feedback and variations in the form of quizzes is the central stimulus in e-learning. However, this phenomenon of online assignment is considered illogical and unrealistic, especially during the Covid-19 pandemic. This condition will have an impact on lecture output.

One of the online lecture outputs collected in this study is student motivation. Based on the research results, the main motivation of students in attending online lectures is to broaden their insights and knowledge, specifically, in the course material related to the global pandemic Covid-19. Other motivations that can be expressed are to get grades, stay active, and improve skills. By pursuing online lectures in earnest, students expect to do assignments or answer questions correctly. Staying at home keeps students from having much activity, and taking online lectures is one of those activities that can keep them energetic, or at least there is something to do, whereas the skills coveted by students through online lectures are to improve their computing experience and mastery of digital technology. The motivation of these students is similar to the research conducted by El-Seoud et al. [3], which states that in addition to grades, students are also motivated to gain new skills from the online college process.

Furthermore, these students' motivation can be divided into four levels: motivated, standardized, frustrated, and depressed. Although most student motivation is at the standard level, many students experience frustration in the second place. The frustration experienced by students is related to the number of assignments given by the lecturer. Even so, there is a small percentage of students feeling depressed. This problem must be taken seriously. Depression felt by students related to limited internet access, lack of internet data, and lack of time make some students feel they left behind in learning. This condition needs to be taken seriously because it will negatively impact students' enthusiasm to continue their studies after the pandemic period ends. Student motivation is seen as the frontline in maintaining the existence of student learning [15].

\section{Conclusion}

This research has revealed how home learning works from the student's perspective. Based on student perceptions, the implementation of e-learning during the global pandemic has three main weaknesses. First, in the preparation stage, the lecturer has not prepared a holistic lesson plan. Second, in the implementation phase, lecturers have not been able to manage online class organizations efficiently, so a lot of time is wasted. Third, in the evaluation phase, the intensity of the assignment is very high. These three weaknesses indirectly affect student motivation in attending online lectures. Although most of the students' motivation is maintained, some students experience frustration, even some of them claim to be depressed. This condition will threaten the sustainability of students' studies. This research has limitations, which is only done in the higher education level. Further research is needed that covers all levels of education. Further research is also needed to examine individually online learning strategies during the global pandemic. Furthermore, it is necessary to develop particular policies that regulate distance education patterns that relate to geographical conditions, socio-economic, and student culture. As well as preparing the teaching staff to be more professional in implementing online learning during the Covid-19 pandemic. 


\section{References}

[1] A. Eftychia, "Home learning activities and children's learning outcomes: a review of recent evidence,” Eur. J. Educ. Stud., vol. 6, no. 1, pp. 100-159, 2019.

[2] T. Almarabeh and H. Mohammad, "E-learning in the jordanian higher education system: strengths, weakness, opportunities, and threats," J. Am. Sci., vol. 9, no. 3, pp. 281-287, 2013.

[3] M. S. A. El-Seoud, I. A. T. Taj-Eddin, and N. Seddiek, "E-learning and students' motivation: a research study on the effect of e-learning on higher education," iJET, vol. 9, no. 4, pp. 20-26, 2014.

[4] D. Folley, “The lecture is dead long live the e-lecture," Electron. J. E-Learning, vol. 8, no. 2, pp. 93-100, 2010.

[5] N. W. Utami, I. K. R. Arthana, and I. G. M. Darmawiguna, "Usability evaluation in e-learning of Universitas Pendidikan Ganesha using usability testing method (in Bahasa)," J. Nas. Pendidik. Tek. Inform. JANAPATI, vol. 9, no. 1, pp. 107-118, 2020.

[6] Silahuddin, "The e-learning implementation in educational innovation (in Bahasa)," J. Ilm. Circuit, vol. 1, no. 1, pp. 48-59, 2015.

[7] M. Jara and H. Mellar, "Quality enhancement for e-learning courses: the role of student feedback,” Comput. Educ., vol. 54, pp. 709-714, 2010.

[8] R. Lawrence, L. F. Ching, and H. Abdullah, "Strengths and weaknesses of education 4.0 in the higher education institution," Int. J. Innov. Technol. Explor. Eng., vol. 9, no. 23, pp. 511-519, 2019.

[9] S. Guri-Rosenblit, "E-teaching in higher education: an essential prerequisite for e-learning," $J$. New Approaches Educ. Res., vol. 7, no. 2, pp. 93-97, 2018.

[10] S. Bajpai, "Proposed framework of e-learning in remote areas of uttarakhand: in perspective with mobile communication,” Int. J. Innov. Sci. Eng. Technol., vol. 2, no. 6, pp. 693-697, 2015.

[11] S. Maudiarti, "E-learning implementation in a higer education (in Bahasa)," Perspekt. Ilmu Pendidik., vol. 32, no. 1, pp. 53-68, 2018.

[12] S. Gon and A. Rawekar, "Effectivity of e-learning through Whatsapp as a teaching learning tool," MVP J. Med. Sci., vol. 4, no. 1, pp. 19-25, 2017.

[13] H. Al-Samarraie, B. K. Teng, A. I. Alzahrani, and N. Alalwan, "E-learning continuance satisfaction in higher education: a unified perspective from instructors and students," Stud. High. Educ., 2017.

[14] L. King et al., Student and Professor Perspectives on Exemplary Practices in the Use of Information and Communication Technologies (ICTs) and e-Learning in Colleges. Montréal, Québec: Réseau de Recherche Adaptech, 2017.

[15] M. A. Prasetya, "E-learning as an innovation of active learning method (in Bahasa)," Edukasia J. Penelit. Pendidik. Islam, vol. 10, no. 2, pp. 319-338, 2015. 